\title{
Patient's Knowledge of Basic Medication Information in Saudi Arabia
}

\author{
Yousef Ahmed Alomi ${ }^{1, *}$, Dima Ahmad Alaskari², Malak Mohammad Almelfi², Dima Ali Badawi ${ }^{3}$, \\ Abdullah Mohammad Alshihri ${ }^{4}$ \\ ${ }^{1}$ The Past General Manager of General Administration of Pharmaceutical Care and The Past Head, National Clinical Pharmacy \\ and Pharmacy Practice and Pharmacy $R$ and D Administration, Ministry of Health, Riyadh, SAUDI ARABIA. \\ ${ }^{2}$ General Administration of Pharmaceutical Care, Ministry of Health, Riyadh, SAUDI ARABIA. \\ ${ }^{3}$ Pharmaceutical Care Services, Saudi Germany Hospital, Aseer, SAUDI ARABIA. \\ ${ }^{4}$ Head, Pharmaceutical Care Services, Abha Maternity and Children Hospital, Abha, SAUDI ARABIA.
}

Received: 02 June 2018;
Accepted: 28 August 2018
*Correspondence to:
Dr. Yousef Ahmed Alomi,
The Past General Manager of General
Administration of Pharmaceutical Care
The Past Head, National Clinical Pharmacy and
Pharmacy Practice
The Past Head, Pharmacy R and D
Administration
Ministry of Health, P.O.BOX 100, Riyadh 11392,
Riyadh, SAUDI ARABIA.
Email: yalomi@gmail.com
Copyright: C) the author(s),publisher and
licensee Indian Academy of Pharmacists. This
is an open-access article distributed under the
terms of the Creative Commons Attribution
Non-Commercial License, which permits
unrestricted non-commercial use, distribution,
and reproduction in any medium, provided the
original work is properly cited.

\begin{abstract}
Objective: To explore the Patients and Basic Knowledge of Medications in Saudi Arabia. Methods: It is a 4-months cross-sectional survey of patient and basic knowledge of medicines. The survey consisted of twopart, demographic information and second part forty-nine questions divided into four domains. It included domain 1: Primary or essential information about patient medication, domain 2: patient information about the drug-related problem, domain 3: patient information about drug-related cost and domain 4: patient's perception about medications. Medline Plus health information and DailyMed-INH elements information from National Institute of Health United State of America were used. The 5-point Likert response scale system was used. The questions were open and closed-ended. The survey distributed through social media and at 500-bed pediatrics and maternity hospital in Asir region, at ambulatory care pharmacy. The authors did the patients interview with electronic survey documentation. The survey was made in an electronic format and it analyzed domain one Primary or necessary information about patient medication through survey monkey system. Results: The total responders were (614) patients with Saudi 564 (96.1\%) and Non-Saudi was 23 (3.9\%) nationalities. The gender distribution 523 (85.2\%) were females and 91 (14.8\%) were males. The most type of medications used was anti-diabetic and anti-hypertension medicines, Skin medications and drugs for Respiratory Diseases. The responders showed poor knowledge either they do not know or weak information about the generic name of Medicines 300 (54.8\%), the trade name 246 (46.8\%). While adequate knowledge both complete and incomplete information of drug strength 324 (60.9\%) and dosage form of medication 377 (70.6\%). The patients showed adequate knowledge about medications with both complete information and incomplete information about drug indication 456 (77.8\%), how to use medications 496 $(84.78 \%)$, the administration time $493(84.71 \%)$, the potential to adhere medication $431(73.9 \%)$ and the time to stop drugs $391(67.1 \%)$. The majority of responders used health care providers 346 (57\%), drug bulletin 341 (56.2\%), Internet 221 (36.4\%) and Relatives and friends 137 (22.57\%) as sources of drug information. Conclusion: The finding showed indigent essential drug information knowledge. Targeting of public awareness of necessary information about their medications and patient counseling system will prevent drug misadventures and drug-related morbidity and mortality in Saudi Arabia.
\end{abstract}

Key words: Patient, Knowledge, Medications, Ministry of Health, Saudi Arabia.

\section{INTRODUCTION}

The pharmacists had a major role in medications information dissemination with drug distribution. ${ }^{[1]}$ The knowledge of medication distribution through several pharmacy services and program included but not limited to drug information services, patient's medication education program, medication safety program and pharmacists intervention system. ${ }^{[2]}$ Several international pharmacy organizations recommended to the established system of medication information distribution system with the previous method..$^{[3-5]}$ The central question behind that was, did the patient need the medication information and the knowledge of drugs? The patient's Knowledge about medications used varies and may lead to incorrect use, causing a decline in effectiveness or appearance of other health problems. When the patient arrives in the conviction and knowledge that treatment taken leads to improved health status, its components and its compounds are safe and there are no side effects. Thus this leads to making patient regulate the use of the drug and keep it to taking at appropriate time prescribed by the doctor. Hence, the importance of showing that the patient is familiar with the treatment used until final results will be positive and help in response to the patient's condition with treatment and because of compliance (adherence) to an essential drug. For the effective medical treatment, there is no doubt that the patient's knowledge has an impact on their diseases and knowledge management of patients that can affect compliance and control of their diseases and the morbidity and mortality of patients. A fundamental pillar to facilitate obtaining excellent results in pharmacotherapy lies in the adequate knowledge of patients regarding their pharmacological treatment. ${ }^{[6-8]}$ Several studies conducted to measure the actual patient medication knowledge. ${ }^{[9-12]}$ 
Those studies were done at hospitals or community pharmacy with a different number of sample and various specialties. Few studies were done in Saudi Arabia with a limited number of patients and limited depth detail. ${ }^{[13-14]}$ It is hard to find investigation to reflect the actual necessary information of medications knowledge with high number of patients and detail information in Saudi Arabia, Gulf or Middle East counties. The objective of this study was to explore the patient's knowledge about medications at ambulatory care visits and through community-based in Kingdom of Saudi Arabia.

\section{METHODS}

It is a 4-months cross-sectional survey of patient and basic knowledge of medicines. The survey consisted of two-part, demographic information and second part forty-nine questions divided into four domains. It included domain 1: Primary or essential information about patient medication, domain 2: patient information about the drug-related problem, domain 3: patient information about drug-related cost and domain 4: patient perception of medications. Medline Plus health information and DailyMedINH elements information from National Institute of Health United State of America were used. ${ }^{[15-16]}$ The 5-point Likert response scale system was used. The questions were open and closed-ended. The survey distributed through social media and at 500-bed pediatrics and maternity hospital in Asir region, at ambulatory care pharmacy. The hospital accredited by Saudi Center for Healthcare organization (CBAHI) and Joint Commission on Hospital Accreditation from the United States of America (USA). ${ }^{[17-18]}$ The hospital's several departments such as Pediatrics, Obstetrics and Gynecology were included. It had Adults, Pediatrics and Neonatal critical care, with the separated nursing unit. In addition to medical and surgical sections for adults, pediatrics and neonates. The pharmacy departments distributed the medication through unit dose system according to CBAHI standards and American Society of Health-System standards. Also, the pharmacy had inpatient pharmacy, outpatient pharmacy, Intravenous Admixture services with professional Total Parenteral Nutrition. The clinical pharmacy services did not entirely exist except some programs for an instant; drug information center, patient-counseling services and medication safety program. The authors did the patients interview with electronic survey documentation. The survey was made in an electronic format and it analyzed domain one Primary or necessary information about patient medication through survey monkey system.

\section{RESULTS}

The total responders were (614) patients with Saudi $564(96.1 \%)$ and Non-Saudi $23(3.9 \%)$ nationalities. The gender distribution $523(85.2 \%)$ were females and $91(14.8 \%)$ were males. The majority of them in age (18-44) 78.3\% and located at Asir region 325 (52.93\%) and Riyadh region 163 (26.54\%). The most patients had the Bachelor Degree 311 (50.65\%) followed by High school 138 (22.48\%) and Diploma 47 (7.65\%). The most type of medications used was anti-diabetic and anti-hypertension medicines, Skin medications and drugs for Respiratory Diseases. Also, the total patient currently taking medication were $249(43.23 \%)$. Of those the most number of medication taken were either one 96 (38.55\%), two medications $79(31.73$ $\% \%$, three medications $25(10.04 \%)$ and four medications $24(10.04 \%)$ as explored in Table 1 . The responders showed poor knowledge either they do not know or weak information about the generic name of Medicines $300(54.8 \%)$, the trade name $246(46.8 \%)$. While adequate knowledge both complete and incomplete information of drug strength $324(60.9 \%)$ and dosage form of medication $377(70.6 \%)$ as explored in Table 2. The patients showed adequate knowledge about medications with both complete information and incomplete information about drug indication $456(77.8 \%)$, how to use medications 496 (84.78\%). The administration time 493 (84.71\%), what to do if forgot one dose $315(54.5 \%)$, the potential to adhere medication $431(73.9 \%)$ and the time to stop drugs $391(67.1 \%)$ as explored in Table 3.

\begin{tabular}{|c|c|c|}
\hline Characteristics & Response N & Response \% \\
\hline \multicolumn{3}{|l|}{ Sex } \\
\hline Female & 523 & $85.2 \%$ \\
\hline Male & 91 & $14.8 \%$ \\
\hline Answered question & 614 & $100 \%$ \\
\hline Skipped question & 0 & \\
\hline \multicolumn{3}{|l|}{ Nationality } \\
\hline Saudi & 564 & $96.1 \%$ \\
\hline Non-Saudi & 23 & $3.9 \%$ \\
\hline Answered question & 587 & $100 \%$ \\
\hline Skipped question & 27 & \\
\hline \multicolumn{3}{|l|}{ Age } \\
\hline$<18$ & 34 & $9.9 \%$ \\
\hline $18-29$ & 267 & $103.0 \%$ \\
\hline $30-44$ & 214 & $60.9 \%$ \\
\hline $45-59$ & 87 & $22.5 \%$ \\
\hline $60+$ & 12 & $3.6 \%$ \\
\hline Answered question & 614 & $100 \%$ \\
\hline Skipped question & 0 & \\
\hline \multicolumn{3}{|l|}{ Total Experiences } \\
\hline Doctorate degree & 7 & $1.14 \%$ \\
\hline Master degree & 17 & $2.77 \%$ \\
\hline Bachelor Degree & 311 & $50.65 \%$ \\
\hline Diploma & 47 & $7.65 \%$ \\
\hline High school & 138 & $22.48 \%$ \\
\hline Intermediate School & 33 & $5.37 \%$ \\
\hline Primary School & 27 & $4.40 \%$ \\
\hline Not educated & 34 & $5.54 \%$ \\
\hline Answered question & 614 & $100 \%$ \\
\hline Skipped question & 0 & \\
\hline \multicolumn{3}{|l|}{ The current medications } \\
\hline Diabetic Medication & 79 & $12.91 \%$ \\
\hline Antihypertensive Medication & 64 & $10.46 \%$ \\
\hline Cardiac Medication & 13 & $2.12 \%$ \\
\hline Asthma Medication & 50 & $8.17 \%$ \\
\hline Derma Medication & 57 & $9.31 \%$ \\
\hline Anti-Rheumatic & 32 & $5.23 \%$ \\
\hline Do not take anything now & 412 & $67.32 \%$ \\
\hline Others & 87 & $14.22 \%$ \\
\hline Answered question & 612 & $100 \%$ \\
\hline Skipped question & 2 & \\
\hline \multicolumn{3}{|c|}{ Number of current medication taken } \\
\hline Nothing & 327 & $56.77 \%$ \\
\hline 1 & 96 & $38.55 \%$ \\
\hline 2 & 79 & $31.73 \%$ \\
\hline 3 & 25 & $10.04 \%$ \\
\hline 4 & 24 & $9.64 \%$ \\
\hline 5 & 13 & $5.22 \%$ \\
\hline 6 & 5 & $2.01 \%$ \\
\hline 7 & 3 & $1.20 \%$ \\
\hline 8 & 0 & $0.00 \%$ \\
\hline 9 & 1 & $0.40 \%$ \\
\hline 10 & 2 & $0.80 \%$ \\
\hline more than 10 & 0 & $0.00 \%$ \\
\hline Answered question & 576 & \\
\hline Skipped question & 38 & \\
\hline
\end{tabular}


Table 2: General Information on used medication.

\begin{tabular}{|l|l|l|l|l|l|l|l|l|} 
No. & Answer Options & $\begin{array}{l}\text { Complete } \\
\text { information }\end{array}$ & $\begin{array}{l}\text { Incomplete } \\
\text { information }\end{array}$ & $\begin{array}{l}\text { Weak } \\
\text { information }\end{array}$ & $\begin{array}{l}\text { I do not } \\
\text { have } \\
\text { information }\end{array}$ & $\begin{array}{l}\text { I do not } \\
\text { need this } \\
\text { information }\end{array}$ & $\begin{array}{l}\text { Rating } \\
\text { Average }\end{array}$ & $\begin{array}{l}\text { Response } \\
\text { Count }\end{array}$ \\
\hline 1 & The generic name & 99 & 102 & 93 & 207 & 46 & 3.00 & 547 \\
\hline 2 & The trade name & 138 & 97 & 94 & 152 & 44 & 3.25 & 525 \\
\hline 3 & The drug strength & 211 & 113 & 76 & 106 & 26 & 3.71 & 532 \\
\hline 4 & Dosage form of medications & 307 & 70 & 49 & 72 & 36 & 4.01 \\
\hline
\end{tabular}

\begin{tabular}{|c|c|c|c|c|c|c|c|c|}
\hline No. & Answer Options & $\begin{array}{l}\text { Complete } \\
\text { information }\end{array}$ & $\begin{array}{l}\text { Incomplete } \\
\text { information }\end{array}$ & $\begin{array}{l}\text { Weak } \\
\text { information }\end{array}$ & $\begin{array}{l}\text { I do not } \\
\text { have } \\
\text { information }\end{array}$ & $\begin{array}{l}\text { I do not } \\
\text { need this } \\
\text { information }\end{array}$ & $\begin{array}{l}\text { Rating } \\
\text { Average }\end{array}$ & $\begin{array}{l}\text { Response } \\
\text { Count }\end{array}$ \\
\hline 1 & Drug Indication & 333 & 123 & 46 & 45 & 39 & 4.14 & 586 \\
\hline 2 & How to use the medications & 419 & 77 & 24 & 33 & 32 & 4.40 & 585 \\
\hline 3 & Medication administration time & 419 & 74 & 26 & 28 & 35 & 4.40 & 582 \\
\hline 4 & What to do if I forgot one dose & 183 & 132 & 77 & 143 & 43 & 3.47 & 578 \\
\hline 5 & $\begin{array}{l}\text { Adherence to medication and it is } \\
\text { important }\end{array}$ & 325 & 106 & 61 & 59 & 32 & 4.09 & 583 \\
\hline 6 & The time to stop treatment & 293 & 98 & 76 & 77 & 39 & 3.91 & 583 \\
\hline
\end{tabular}

Table 4: The resources of Drug Information.

\begin{tabular}{|l|l|l|}
\hline Answer Options & Response N & Response \% \\
\hline Health practitioners & 346 & $57.00 \%$ \\
\hline Drug Bulletin & 341 & $56.18 \%$ \\
\hline Relatives and friends & 137 & $22.57 \%$ \\
\hline The Internet & 221 & $36.41 \%$ \\
\hline Drug Information Center at the hospital & 54 & $8.90 \%$ \\
\hline lecture in hospital & 11 & $1.81 \%$ \\
\hline Lectures in health center & 6 & $0.99 \%$ \\
\hline Drug education in markets Exhibition & 10 & $1.65 \%$ \\
\hline Other (please specify) & 6 & $0.99 \%$ \\
\hline answered question: 607 and skipped question: 7 & \\
\hline
\end{tabular}

The majority of responders used health care providers $346(57 \%)$, drug bulletin 341 (56.2\%), Internet 221 (36.4\%) and Relatives and friends 137 $(22.57 \%)$ as sources of drug information as explored in Table 4.

\section{DISCUSSION}

The General administration of pharmaceutical care at Ministry of Health in Saudi Arabia released the updated vision and mission of the administration within period 2012-2020. ${ }^{[19]}$ The main concept of both vision and mission was medication and their knowledge distribution to all the type of patients. The pharmacy administration established several services to facilitate that vision and mission, for instant national drug information centers, participated though $\mathrm{MOH}$ hotline 937, established the patient education program, medications safety system for patient and healthcare professionals and patients' satisfaction of pharmacy services. ${ }^{[20-22]}$ Those services demanded several committees, meeting, policy and procedures activities, time and money and a lot of pharmacist's effort. Although of significant improvement of the pharmacy services over the past years, the questions raised does the patient need all those services to distribute the medication and drug knowledge. Was the patient had poor knowledge implicated them to mistakes and problems, what is the level of medication's knowledge of patients in Kingdom of Saudi Arabia? To answer all those inquiries, the investigator and his team tried to explore the fundamental patient knowledge of medications. The finding of the study showed half of the patients were not familiar with generic of trade drug name. This result was lower than what reported by Rubio JS et al. in Portugal and better than what reported by Perera, $\mathrm{T}$ et al. in Sri Lanka. That has related proper health education and speaking in the English language while poor health education in Sri Lanka and English language. ${ }^{[11-12]}$ While in our country, the study has shown acceptable English language and health education. The results of drug strength, dosage form, drug indications, how to use medication, administration time resemble what reported by Rubio JS et al. in Portugal and better than in drug doing what reported by Perera, $\mathrm{T}$ et al. in Sri Lanka with same previous reasons. ${ }^{[11-12]}$ Another result of what to do if patient forgot one dose, the potential to adhere medication could not compare it because it did not mention in both studies. Most of the patient got their drug knowledge from healthcare providers looks like what reported by Williams, L et al. as first choice, the second resources of medication knowledge was drug bulletin and internet different what reported by Williams, L et al. reported their relatives. That is because our population was younger than previous study and they were familiar with reading drug bulletin and using internet available everywhere as comparisons of a study published before ten years. Based on the results, we can deduce that patients know some information about their medications, but not all. Especially the name of the medicine they use. This study identified some key themes that might be useful in enhancing the awareness of experiences, knowledge, adherence and attitudes of patients. More efforts of pharmacy public education of their medication and a patient counseling educational program are also required to practice a healthy life. ${ }^{[23]}$

\section{CONCLUSION}

The results obtained showed a lack of knowledge among patients, essential drug information knowledge. Targeting of public awareness of necessary 
information about their medications and patient counseling system will prevent drug misadventures and drug-related morbidity and mortality in Saudi Arabia.

\section{ACKNOWLEDGMENT}

None

\section{CONFLICT OF INTEREST}

None

\section{ABBREVIATIONS}

KSA: Kingdom of Saudi Arabia; MOH: Ministry of Health; CBAHI: Saudi Center for Accreditation of Healthcare Institutions.

\section{REFERENCES}

1. Pedersen CA, Schneider PJ, Scheckelhoff DJ. ASHP national survey of pharmacy practice in hospital settings: Dispensing and administration - 2014. Am J Heal Pharm. 2015;72(13):1119-37.

2. Pedersen CA, Schneider PJ, Scheckelhoff DJ. ASHP national survey of pharmacy practice in hospital settings: Monitoring and patient education-2015. Am J Heal Pharm. 2016;73(17):1307-30.

3. Ghaibi S, Ipema H GM. ASHP Guideline on The Pharmacist's Role in Providing Drug Information. Am J Heal Pharm. 2015;72(7):573-7.

4. Lim LY, Chui WK. Pharmacist-operated drug information centers in Singapore. J Clin Pharm Ther. 1999;24(1):33-42.

5. Alsultan MS, Mayet AY, Khurshid F, Al-jedai AH. Hospital pharmacy practice in Saudi Arabia: Drug monitoring and patient education in the Riyadh region. Saudi Pharm J. 2013;21(4):361-70.

6. Rubio JS, García DP, Iglésias FP, Mateus SH, Martínez MF, Rubio JS, et al. Measurement of patients' knowledge of their medication in community pharmacies in Portugal. Cien Saude Colet. 2015;20(1):219-28.

7. Burge S, White D, Bajorek E, Bazaldua O, Trevino J, Albright T, et al. Correlates of medication knowledge and adherence: Findings from the Residency Research Network of South Texas. Fam Med. 2005;37(10):712-8.

8. Wooldridge K, Schnipper JL, Goggins K, Dittus RS, Kripalani S. Refractory primary medication nonadherence: Prevalence and predictors after pharmacist counseling at hospital discharge. J Hosp Med. 2016;11(1):48-51.

9. Williams L, Caskey H, Coates V, Thompson K, Helen S. A survey of patients' knowledge of their diabetes medication. J Diabetes Nurs. 2007;11(7):264-9.

10. Jodlowski TZ, Sym D, Conry J, Kanmaz T. Antiretroviral medication knowledge among New York State pharmacists: room for improvement. J Pharm Pract. 2010;23(5):507-10.

11. Perera T, Ranasinghe P, Perera U, Perera S, Adikari M, Jayasinghe S, et al. Knowledge of prescribed medication information among patients with limited English proficiency in Sri Lanka. BMC Res Notes. 2012;5(1):658.

12. Rubio JS, García DP, Iglésias FP, Mateus SH, Martínez MF. Measurement of patients' knowledge of their medication in community pharmacies in Portugal. Cien Saude Colet. 2015;20(1):219-28.

13. Zaki NM, Albarraq AA. Use, attitudes and knowledge of medications among pregnant women: A Saudi study. Saudi Pharm J. 2014;22(5):419-28.

14. Alshammari TM. Patient's medicinal knowledge in Saudi Arabia: Are we doing well?. Saudi Pharm J. 2016;24(5):560-2.

15. MedlinePlus - Health Information from the National Library of Medicine. Available from: https://medlineplus.gov/

16. DailyMed. Available from: https://dailymed.nlm.nih.gov/dailymed/

17. Medication Management (MM). In: National Hospital Standards. $2^{\text {nd }}$ Editio. Saudi Central Board for Accreditation of Healthcare Institutions.; 2015;194-211. Available from: http://www.cbahi.gov.sa

18. The Joint Commission. Comprehensive Accreditation Manuals. Joint Commission Resources. Available from: http://www.jcrinc.com/store/publications/manuals/

19. Alomi YA, Alghamdi SJ, Alattyh RA. Strategic Plan of General Administration of Pharmaceutical Care at Ministry of Health in Saudi Arabia 2012-2022. J Pharm Pharm Sci. 2015;1(3):1-8.

20. Alomi YA. National Pharmacy Administration Programs at Ministry of Health in Saudi Arabia. BAOJ Pharm Sci. 2015;1(9).

21. Alomi YA. National Medication Safety Program at Ministry of Health in Saudi Arabia. J Pharmacovigi. 2015;3(5):1-2.

22. Alomi YA. Patient satisfaction of pharmaceutical care system at Ministry of Health in Saudi Arabia. BAOJ Pharm Sci. 2016;2:19.

23. Al-Qazaz HK, Hassali MA, Shafie AA, Syed Sulaiman SA, Sundram S. Perception and knowledge of patients with type 2 diabetes in Malaysia about their disease and medication: A qualitative study. Res Soc Adm Pharm. 2011;7(2):180-91.

Cite this article as: Alomi YA, Alaskari DA, Almelfi MM, Badawi DA, Alshihri AM. Patient's Knowledge of Basic Medication Information in Saudi Arabia. J Pharm Pract Community Med. 2018;4(3):175-8. 